University of Nebraska - Lincoln

DigitalCommons@University of Nebraska - Lincoln

US Army Research

U.S. Department of Defense

2012

Sediment budget possibilities and improbabilities

Todd L. Walton Jr.

Florida State University, twalton@fsu.edu

Robert G. Dean

University of Florida, dean@coastal.ufl.edu

Julie D. Rosati

U.S. Army Corps of Engineers, Julie.D.Rosati@usace.army.mil

Follow this and additional works at: https://digitalcommons.unl.edu/usarmyresearch

Walton, Todd L. Jr.; Dean, Robert G.; and Rosati, Julie D., "Sediment budget possibilities and improbabilities" (2012). US Army Research. 233.

https://digitalcommons.unl.edu/usarmyresearch/233

This Article is brought to you for free and open access by the U.S. Department of Defense at DigitalCommons@University of Nebraska - Lincoln. It has been accepted for inclusion in US Army Research by an authorized administrator of DigitalCommons@University of Nebraska - Lincoln. 
Short communication

\title{
Sediment budget possibilities and improbabilities
}

\author{
Todd L. Walton Jr. ${ }^{\mathrm{a}, *}$, Robert G. Dean ${ }^{\mathrm{b}}$, Julie D. Rosati ${ }^{\mathrm{c}}$ \\ a Beaches and Shores Research Center, Institute of Science and Public Affairs, Florida State Univ., 2035 E. Paul Dirac Dr. Morgan Bldg., Box 5, Tallahassee, FL 32310, United States \\ b Civil and Coastal Engineering Dept., Univ. of Florida, Weil Hall, Gainesville, FL, United States \\ c Coastal Hydraulics Laboratory, Engineering Research and Development Center, U.S. Army Corps of Engineers, Vicksburg, MS, United States
}

\section{A R T I C L E I N F O}

Article history:

Received 10 April 2011

Accepted 23 August 2011

Available online 19 September 2011

\section{Keywords:}

Beach

Inlet

Linear algebra

Matrix algebra

Sand

Sediment bypassing

Sediment budget

Sediment management

Waves

\begin{abstract}
A B S T R A C T
Problems of constructing a sediment budget for an inlet is often a challenge due to constraints on data collection, quality of data, and assumptions one is willing to consider. Existing literature does not provide a systematic foundation for equations considered and often engineers and geologists typically do not properly consider the mathematical constraints placed on the problem of sediment budget construction. The present technical note presents a simple methodology for assessing sediment budget, i.e. what is possible, and what is not possible via a matrix equation system and linear algebra. It is hoped that engineers and geologists will not impose unrealistic expectations on the sediment budget system via using such an approach. Some simple examples are given of both pitfalls and correct approaches to sediment budget development.
\end{abstract}

(c) 2011 Elsevier B.V. All rights reserved.

\section{Sediment budget discussion}

The problems of constructing sediment budgets for inlets is not new, but is always a challenge due to constraints on data collection, quality of data, and assumptions the engineer or geologist is willing to make. Various literature exists on sediment budget construction (see for example, Jarrett (1991), Bodge (1999), Rosati and Kraus (1999), Dean and Dalrymple (2002), U.S.A.C.E. (2003), Rosati (2005) and others) although previous discussions have not typically addressed the mathematical constraints placed on the problem of properly constructing a sediment budget. The present technical note presents another way of looking at what is possible and what is not possible in sediment budget development via the matrix equations utilized in developing the sediment budget with the hope that engineers and geologists will be careful in addressing sediment budget development without imposing unrealistic expectations on the system.

A first consideration in setting up a sediment budget is to define the quantities desired (i.e. unknowns) and the quantities that are assumed known (i.e. measured or calculated). To establish the procedure followed in this technical note, a simplified first example will be provided as shown in Fig. 1 which is a 3 cell sediment budget with 4 assumed knowns (i.e. the volume change within the cell and the net sediment

\footnotetext{
* Corresponding author.

E-mail addresses: twalton@fsu.edu (T.L. Walton), dean@coastal.ufl.edu (R.G. Dean), Julie.D.Rosati@usace.army.mil (J.D. Rosati).
}

transport at the downdrift boundary of the downdrift cell) and 3 unknowns (i.e. entering and exiting quantities at the intermediate boundaries of the cells along with the net sediment transport at the updrift boundary of the updrift cell). In Fig. 1, the updrift side of the inlet is represented by the cell on the left (i.e. cell 1), while the downdrift side of the inlet is represented by the cell on the right (i.e. cell 3). The middle cell (cell 2) is the cell with the inlet in it. In this first example, using one equation for each cell, continuity balance allows for the 3 equations as follows:

$$
\begin{aligned}
& Q_{\mathrm{n} u}-Q_{\mathrm{su}}=\frac{d V_{1}}{d t} \\
& Q_{\mathrm{su}}-Q_{\mathrm{sd}}=\frac{d V_{2}}{d t} \\
& Q_{\mathrm{s} d}-Q_{\mathrm{n} d}=\frac{d V_{3}}{d t}
\end{aligned}
$$

where $Q_{i j}$ represents the sediment transport in/out of the cell with the subscripts " $n$ " referring to net, " $u$ " referring to updrift, "s' referring to shoal/inlet, "d" referring to downdrift, and where $\frac{d V_{i}}{d t}$ represents the volume change within the "i" cell.

As might be expected, since we have 3 equations and 3 unknowns, this system can be solved to provide an "exact" answer (albeit based on the assumptions made). In the present note, the equations are set up in matrix form, the reasons for which will become clear in further "seemingly simple" examples. Upon establishing the matrix form with the "unknowns' on the left side of the equations and the "knowns" on 


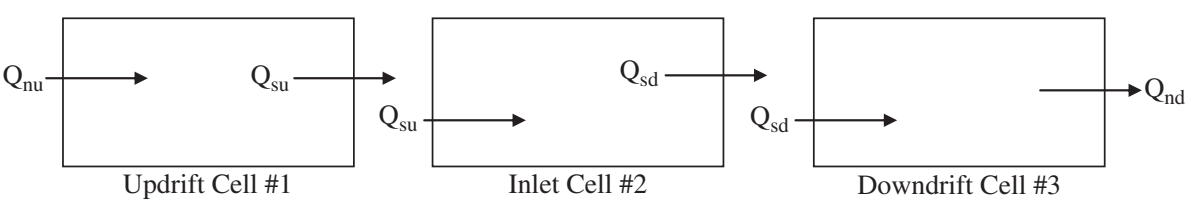

Fig. 1. Three cell sediment budget without bypassing.

the right side of the equations, the matrix system can be shown to be of the following form:

$$
\left[\begin{array}{ccc}
1 & -1 & 0 \\
0 & 1 & -1 \\
0 & 0 & 1
\end{array}\right] \cdot\left[\begin{array}{c}
Q_{n u} \\
Q_{s u} \\
Q_{s d}
\end{array}\right]=\left[\begin{array}{c}
\frac{d V_{1}}{d t} \\
\frac{d V_{2}}{d t} \\
\frac{d V_{3}}{d t}+Q_{n d}
\end{array}\right]
$$

and using matrix shorthand notation for the above quantities the equation system can be written as:

$A \cdot \hat{\mathrm{Q}}=R H S$

where $A$ is the matrix of 0 's, 1 's, and -1 's, $\hat{Q}$ is the vector of "unknowns", and RHS is the right hand side matrix of "knowns". The solution (for the "unknowns") to this expression can be simply stated as:

$\hat{\mathrm{Q}}=A^{-1} \cdot R H S$

where $A^{-1}$ is the inverse of $A$. As long as $A$ has an inverse, then the equations can be solved exactly and in this case the inverse of $A$ can be easily found as:

$A^{-1}=\left[\begin{array}{lll}1 & 1 & 1 \\ 0 & 1 & 1 \\ 0 & 0 & 1\end{array}\right]$

Let's assume now that for the same sediment budget system, that both the net updrift sediment transport $Q_{n u}$, and the net downdrift sediment transport $Q_{n d}$ are known. We still have three equations for the three sediment cells but we now only have 2 unknowns. This presents us with a possibility of dropping one of the equations and getting an answer with only 2 equations and 2 unknowns, but an advantage of keeping all three equations can be gained via using a least squares solution, therefore allowing some possible error in the quantities assumed, but yet giving us a "best" answer to our problem. For this case the following equations are used:

$-Q_{s u}=\frac{d V_{1}}{d t}-Q_{n u}$

$\mathrm{Q}_{s u}-\mathrm{Q}_{s d}=\frac{d V_{2}}{d t}$

$\mathrm{Q}_{s d}=\frac{d V_{3}}{d t}+\mathrm{Q}_{n d}$

where again, the "unknowns" are on the left side and "knowns" on the right side of the equations. This set of equations can be written in matrix form as:

$$
\left[\begin{array}{cc}
-1 & 0 \\
1 & -1 \\
0 & 1
\end{array}\right] \cdot\left[\begin{array}{l}
Q_{s u} \\
Q_{s d}
\end{array}\right]=\left[\begin{array}{c}
\frac{d V_{1}}{d t}-Q_{n u} \\
\frac{d V_{2}}{d t} \\
\frac{d V_{3}}{d t}+Q_{n d}
\end{array}\right]
$$

or in the same matrix shorthand form as before (although with modified matrix definitions):

$A \cdot \hat{\mathrm{Q}}=R H S$

In this situation as the equation system is overdetermined (i.e. more equations than unknowns) and correspondingly the $A$ matrix is not square, so the "best" solution is a "least squares" solution provided by:

$\hat{\mathrm{Q}}=\left(A^{T} \cdot A\right)^{-1} \cdot\left(A^{T} \cdot R H S\right)$

where $A^{T}$ is the matrix transpose of $A$ and where it is assumed that the inverse of $\left(A^{T} \cdot A\right)$ exists (which it does in this case and can be found as

$$
\left(A^{T} \cdot A\right)^{-1}=\left[\begin{array}{ll}
\frac{2}{3} & \frac{1}{3} \\
\frac{1}{3} & \frac{2}{3}
\end{array}\right] .
$$

At this point it is tempting to imagine that if we could add an additional equation using the overall sediment budget (of all 3 cells) then we would have 4 equations and 4 unknowns and thus be able to solve all the unknowns in our problem. The overall constraint equation for the three cells combined can be found as:

$Q_{\mathrm{n} u}-Q_{\mathrm{n} d}=\frac{d V_{1}}{d t}+\frac{d V_{2}}{d t}+\frac{d V_{3}}{d t}$

which leads to a matrix expression to be solved as:

$$
\left[\begin{array}{cccc}
1 & -1 & 0 & 0 \\
0 & 1 & -1 & 0 \\
0 & 0 & 1 & -1 \\
1 & 0 & 0 & -1
\end{array}\right] \cdot\left[\begin{array}{c}
Q_{n u} \\
Q_{s u} \\
Q_{s d} \\
Q_{n d}
\end{array}\right]=\left[\begin{array}{c}
\frac{d V_{1}}{d t} \\
\frac{d V_{2}}{d t} \\
\frac{d V_{3}}{d t} \\
\frac{d V_{1}}{d t}+\frac{d V_{2}}{d t}+\frac{d V_{3}}{d t}
\end{array}\right]
$$

or using matrix shorthand notation as before (although with modified matrix definitions):

$A \cdot \hat{\mathrm{Q}}=R H S$

In this case the inverse of $A$ is singular though as might be expected since the equations are not independent! As is readily seen, the 4th equation is a simple combination of the first three equations (i.e. adding the first 3 equations leads to the 4th equation and no information is gained). The point to be made is that in sediment budgets of 3 cells as shown here, one cannot expect to solve for all unknowns and added information must be provided (perhaps the ratio of net drifts at the left and right ends of the system).

At this point it is instructive to look at another aspect of sediment budgets that is important to the subject of natural sediment bypassing on the outer bar of an inlet and it's implications. This situation is presented in Fig. 2 which is similar to Fig. 1 but with the assumption of a natural bypassing route for sediment on the outer ebb shoal of the 


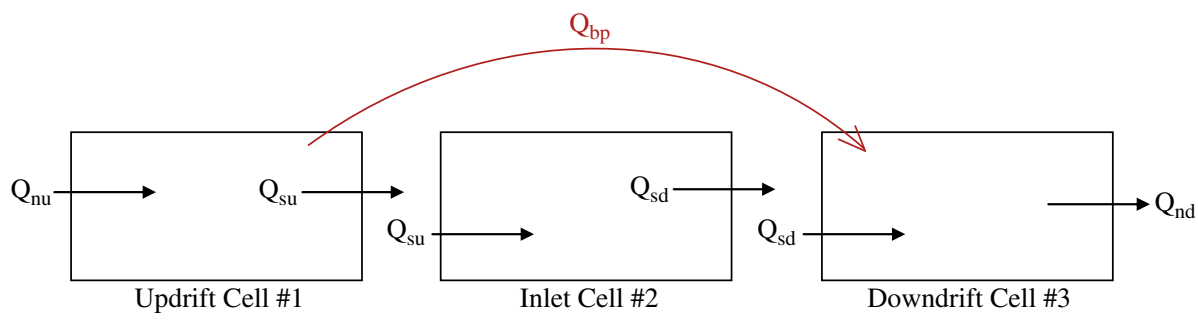

Fig. 2. Three cell sediment budget with bypassing.

inlet. In this case the sediment rate assumed to be directly bypassed on the outer bar (from the updrift to the downdrift beaches) is given by $Q_{b p}$ and where other quantities are provided as before. Both updrift and downdrift net sediment transport quantities are known at the ends of the system and the intent is to find the 3 unknowns provided on the left hand side of the matrix equation given below:

$$
\left[\begin{array}{ccc}
1 & 0 & 1 \\
0 & 1 & 1 \\
1 & -1 & 0
\end{array}\right] \cdot\left[\begin{array}{c}
Q_{s u} \\
Q_{s d} \\
Q_{b p}
\end{array}\right]=\left[\begin{array}{c}
Q_{n u}-\frac{d V_{1}}{d t} \\
\frac{d V_{3}}{d t}+Q_{n d} \\
\frac{d V_{2}}{d t}
\end{array}\right]
$$

where the lines of the respective matrix equation represent the continuity balance of the updrift, downdrift, and inlet cells respectively. Again the system can be expressed in shorthand notation as:

$$
A \cdot \hat{\mathrm{Q}}=R H S
$$

Attempting to solve this equation again leads to the fact that the $A$ matrix is singular, therefore the solution cannot be found without further constraints such as either $Q_{s u}$ or $Q_{s d}$ are zero. The point to be made is that even such a simple system as provided above cannot be solved to assess the inlet's natural bypassing without careful assessment of required assumptions.

\section{Summary}

Methods have been presented to assess the possibility of solving sediment budget unknowns via sediment budget matrix equations without prior knowledge of magnitudes or directions of sediment rate quantities in the sediment budget. Additional assessment has been made showing where equations can be solved and where added assumptions or constraints need to be made (or clarified) in order to solve a sediment budget at an inlet. Specific informational constraints regarding natural bypassing and net transports at boundaries have been addressed and some limitations on what information can be derived from a sediment budget addressed. It is hoped that the value found in the approach utilized herein will encourage both engineers and geologists to clearly state sediment budget assumptions and correctly address sediment budgets such that best management of sand resources will be practiced at inlets.

\section{Acknowledgments}

The author would like to thank the Florida Department of Environmental Protection-Bureau of Beaches and Coastal Systems, Bureau Chief, Mike Barnett, and Coastal Engineering Chief, Bob Brantly, for their support and the opportunity to do research on inlets and beaches.

\section{References}

Bodge, K.R., 1999. Inlet impacts and families of solutions for inlet sediment budgets. Proceedings, Coastal Sediments '99. American Society of Civil Engineers, Reston, VA, pp. 703-718.

Dean, R.G., Dalrymple, R.A., 2002. Coastal Processes. Cambridge University Press, Oxford, UK. (475p).

Jarrett, J.T., 1991. Coastal sediment budget analysis techniques. Proceedings Coastal Sediments '91. American Society of Civil Engineers, Reston, VA, pp. 2223-2233.

Rosati, J.D., 2005. Concepts in sediment budgets. Journal of Coastal Research 21 (2), 307-322 (West Palm Beach, Florida).

Rosati, J.D., Kraus, N.C., 1999. Formulation of sediment budgets at inlets. Coastal Engineering Technical Note CETN-IV-15, U.S. Army Engineer Research and Development Center. Coastal and Hydraulics Laboratory, Vicksburg, MS (20p).

U.S. Army Corps of Engineers, 2003. Sediment Management at Inlets, Coastal Engineering Manual, Part 5, Chapter 6, EM 1110-2-1100, Washington, D.C. 